\title{
The Power of Community School Councils in Urban Schools
}

\author{
Monica A. Medina, Jim Grim, Gayle Cosby \& Rita Brodnax
}

To cite this article: Monica A. Medina, Jim Grim, Gayle Cosby \& Rita Brodnax (2020): The Power of Community School Councils in Urban Schools, Peabody Journal of Education, DOI: 10.1080/0161956X.2019.1702425

To link to this article: https://doi.org/10.1080/0161956X.2019.1702425

册Published online: 30 Jan 2020.

Submit your article to this journal $₫$

Q View related articles $₫$

View Crossmark data $₫$ 


\title{
The Power of Community School Councils in Urban Schools
}

\author{
Monica A. Medina ${ }^{a}$, Jim Grima, Gayle Cosby ${ }^{a}$, and Rita Brodnax ${ }^{b}$ \\ andiana University, Indianapolis, Indiana; 'brodnax's Better Brains, Indianapolis, Indiana
}

\begin{abstract}
Demand for school reform, particularly urban schools labeled as "failing," requires a community engagement strategy centered on intermingled social problems: poverty, racial isolation and discrimination, cultural clashes, socio-economic inequalities, and funding disparities. While school administrators are challenged to turn schools around with limited time and resources quickly, their efforts are not a silver bullet. Engaging community requires committed partnerships that support schools to advance quality learning. Community school councils, an organizing strategy, focus on addressing potential threats and enhancing strengths for student success. This case study describes the participatory action structure of community school councils in an urban public high school, a middle school, and three elementary schools. The theoretical framework of the study is based on Bryk's five essential elements of school improvement and their interplay that predicts school improvement or stagnation in the long term (Bryk et al., 2010) and more recent findings that community schools demonstrate an evidence-based strategy for equitable school improvement. This study is relevant to school communities with comparable demographics interested in a comprehensive strategy that expands the traditional educational mission to address social/emotional and health needs of children and families by engaging the broader community to support student learning, strengthening families and school communities.
\end{abstract}

\section{Introduction}

Community school partners incorporate a wide range of organizations concerned with education, including universities, youth and family serving agencies, and faith-based, neighborhood, and civic groups. Although the nature of the partnerships varies by community, research shows that the active collaborative engagement is essential to the successful implementation of the supports (Oakes, Maier, \& Daniel, 2017). Key lessons learned in best practices for such community school council engagement feature authentic collaboration to address complex social issues (Grim, Medina, \& Officer, 2011). Factors include consistent and structured engagement; shared vision for youth, families, and neighborhoods; as well as student achievement, school leadership participation, stakeholder parity, and equity; ongoing data review; partnership/service inventory; shared responsibility; advocacy; and assessment. The ongoing data review includes the identification of internal and external strengths and threats to academic performance and school success. As a result, impact includes coordination and alignment of supports, data-informed decision-making, authentic parent and community engagement, and strengthening leadership skills for youth and family members. The study of school leadership emphasizes the importance of engaging a school community in improving school performance and academic success (Biag \& Castrechini, 2014; Epstein, 2009).

In urban school communities, increasing economic inequality and residential segregation have generated an interest in community school councils (CSC); thus, school improvement approaches 
Table 1. Community schools demographics.

\begin{tabular}{lccccccc}
\hline School Name & Total Enrollment & White & Black & Latinx & Other Race $\%$ & Attendance & Free/Reduced Lunch \\
\hline High School & 612 & $25 \%$ & $31 \%$ & $38 \%$ & $0.6 \%$ & $81.2 \%$ & $74 \%$ \\
Happy Middle School & 517 & $8 \%$ & $29 \%$ & $58 \%$ & $5 \%$ & $99.7 \%$ & $81.3 \%$ \\
Johnson Elementary & 301 & $7 \%$ & $52 \%$ & $40 \%$ & $1 \%$ & $99.5 \%$ & $80.5 \%$ \\
Wood Elementary & 412 & $46 \%$ & $13.3 \%$ & $31.3 \%$ & $9.4 \%$ & $94.3 \%$ & 82.3 \\
Pencil Elementary & 658 & $34.4 \%$ & $12.5 \%$ & $48.6 \%$ & $4.5 \%$ & $95.9 \%$ & $78.6 \%$ \\
\hline
\end{tabular}

must emphasize the shared responsibility that families, schools, and communities have for our children's education and school reform. Strong research undergirds the notion of community school councils: "a strategy for organizing the resources of the community around student success" (Lubell, 2011, p. 1). Community school councils contribute to high-quality schools by strengthening struggling communities and helping students and families thrive. As a community approach, the coordinated services and programs consist of educational, developmental, family, health, and other comprehensive services through community-based organizations and public and private partnerships (Lubell, 2011).

The CSC is a coalition of educators, parents, community members, and service providers who focus on addressing the needs of all students and identifying community assets to improve youth development that can lead to academic success. Members of the CSC recognize the social and economic forces that constrain the lives of families who are financially vulnerable and therefore work to provide the services and resources to increase positive youth development, student performance, and academic achievement. The CSC becomes a critical partner through consistent and structured engagement and shared vision for youth, families, and neighborhoods. According to Bryk et al. (2010), a school's ability to effectively collaborate with community organizations directly increases the effectiveness of supplemental services to support students and promote learning. Thus, the social network of the CSC helps develop collaborative, trusting relationships among the CSC members, a shared sense of responsibility, and the development of social capital (Bourdieu, 1986). While social capital does not directly alleviate poverty, the formation of strong school/community relationships facilitates the ability to garner needed assets and power to advocate more programs and services for their community (Warren, Thompson, \& Saegert, 2001).

Although the literature on community schools includes research on school improvement (Maier, Daniel, Oakes, \& Lam, 2017), few studies focus on the pivotal role of the CSC in developing and upholding the community school model in an ever-changing urban public school system. This case study highlights how five urban community school councils have evolved into action organizations by promoting community school standards as an evidence-based strategy to uphold equity and educational excellence for every child, their families, and community (Bryk, 2010).

Given the malicious role of poverty in students' lives and learning opportunities, educators must continue to search for strategies that improve student academic achievement and address the needs of the whole child, while establishing authentic social capital. Specifically, we are interested in learning how community school councils organizationally navigate the needs of the school as they grapple with the functions and responsibilities of serving the whole child while keeping a keen focus on learning. This study sought to answer the following three essential questions:

- What community school council practices support and align the site-level implementation of community schools?

- What are the experiences of the community school councils in implementing the critical foundational components of the community school model: Collaborative Leadership, Focused Curriculum and Instruction, Family and Community Engagement, and Integrated, Supportive Student Environment? 
- Are there additional foundational components of the community school model that the schools used for successful implementation and sustainability?

\section{The legacy of the community school model in the community}

This Midwest, urban city has a long history of developing community schools. More than 25 years ago, the Bridges to Success (BTS) initiative began in six elementary schools, and thousands of students enrolled in the school district benefited from the BTS partnerships. Recognized nationally as a particularly promising community schools initiative, the legacy of BTS remains intact as the community school model continues to evolve within different schools throughout the district. As an interdisciplinary, evidence-based initiative, community schools have provided a sense of stability to many of the students and families in two distinct Indianapolis neighborhoods, as both communities in the school district have received funding from the United States Department of Education (USDOE) to develop community schools. The authors have spent more than five years in close partnership with the urban community schools; yet, despite ongoing administrative and policy changes in the school district, the evolution of community schools persists as evidenced by the three USDOE grants awarded to nonprofit entities in the city.

This case study looks at the way the five urban public schools assume the responsibility of organizing and supporting a community school model (see Table 1). We applied a conceptual framework that centers on the Bryk et al. (2010) framework for organizing community schools. The research identifies five organizational features of schools that interact with classrooms, are essential to advancing student achievement, and can predict school improvement or stagnation in the long term. Bryk et al. (2010) state that the way we organize schools is critical for student achievement; therefore, to improve schools, there must be coherent, orchestrated action across all five essential supports. The five essential elements are as follows: (1) collaborative school leadership, (2) authentic parent and community ties, (3) professional capacity of the faculty, (4) positive learning climate, and (5) instructional guidance on school improvement.

As we reviewed the data, we also considered the tenants of high-quality schools, specifically the research of Oakes et al. (2017). This comprehensive review of community school research identifies four standard features in community schools, including (1) integrated support services, (2) expanded learning time opportunities, (3) shared leadership in developing family and community engagement, and (4) collaborative leadership and practice in creating a culture of shared responsibility and collective trust (Maier, Daniel, Oakes, \& Lam, 2017). Individually and collectively, the four pillars serve as structures, practices, or processes that support schools to instantiate the conditions and practices that enhance their effectiveness and help surmount barriers to providing high-quality learning opportunities in low-income communities (Maier, Daniel, Oakes, \& Lam, 2018).

Below are the demographics for the five schools. In the descriptions of the schools, we have given them pseudonyms.

\section{Western Community High School (WCHS)}

Western Community High School (WCHS), located on the city's near-westside, has a total enrollment of 612 students. The demographic breakdown of the school is $25 \%$ white, $31 \%$ African American, 38\% Latinx, $6 \%$ other race, and $74 \%$ of the students qualify for free or reduced lunch. This school is one of the first schools to implement a comprehensive community school approach in the city and has an active community school council with about 70 partners, offering services in 13 areas during and after school hours. This community school initiative has received funding from two USDOE grants to develop full-service community schools and has won several national awards for the initiative, including the inaugural National Community Award from the Coalition for 
Community Schools in 2006. The biggest challenge has been keeping the school principal for more than a couple of years; six principals have served the school in the past ten years.

\section{Happy Middle School}

Happy Middle School, one of only three middle schools in the public school district, considers itself a student focused environment that values community, relationships, and the development of the whole person.

The seventh- and eighth-grade choice middle school near the heart of downtown Indianapolis features 517 students with a demographic breakdown of 58\% Latinx, 29\% African American, 8\% white, and $5 \%$ other race; $81.3 \%$ qualify for free or reduced lunch, and the school averages a $99.7 \%$ daily student attendance. It is an autonomously led school, meaning school leadership has broader leeway in making day-to-day school decisions than most others throughout the district. Additionally, the school has demonstrated success in the implementation of a positive-based intervention system for student behavior that has helped to reduce suspensions and expulsions. Empathy is considered a shared core value, reflected by being named the 2018 Middle School National Kindness Champion. The principal spent much of his pre-administration teaching years at the community high school across the city, which is also featured in this study.

\section{Johnson Elementary School}

Johnson Elementary School on the far northwest side of the city is traditionally one of the highest achieving schools in the district. A vast majority of the students walk to and from the building that is tucked inside a neighborhood of family homes and next to a city park. The pre-K through 6th-grade school's mission is "to create a safe and caring environment where children are inspired and encouraged to become successful, respectful, literate, and independent citizens" (Our History/ Mission - Indianapolis Public Schools, n.d., para. x). The student population totals 301 with a demographic breakdown of 52\% African American, 40\% Latinx, 7\% white, and 1\% other race; 80.5\% qualify for free or reduced lunch, and the school averages a $99.5 \%$ daily student attendance. The principal, who has served as the school leader for more than ten years (a notable tenure rarity these days in this district), embraces the community council strategy for its collaborative, accumulative impact for students, their families, and the neighborhood. He begins each meeting with an update of student achievement data and makes a concerted effort to personally participate in ongoing neighborhood meetings and events.

\section{Wood Elementary School}

Wood Elementary School is an elementary/middle school with a total enrollment of 412 students. This school serves students in kindergarten through 8th grade. The student demographics of this school are $46 \%$ white, $13.3 \%$ African American, 31.3\% Latinx, and 9.4\% other race. More than $82 \%$ of the students qualify for free or reduced lunch, and the school averages a $94.3 \%$ daily attendance rate. The principal is brand new this year. The school offers an afterschool program called RightFit three times a week that includes a hot dinner and transportation home. Embedded within the RightFit program are academic assistance/homework help, physical education, and lessons on nutrition, three critical components of the community school model. The school has had a nearly 30 year partnership with a major grocery store chain that provides support for each classroom.

\section{Pencil Elementary School}

Pencil Elementary School serves grades kindergarten through eighth grade and has a total enrollment of 658 students. The school is also located near Wood Elementary School and the high school. 
The demographics of this school are 34.4\% white, 12.5\% African American, 48.6\% Latinx, and 4.5\% other race. The average daily attendance rate is $95.9 \%$. The percentage of students qualifying for free or reduced lunch is $78.6 \%$. The principal this year is new to this building, but is a veteran leader in the district, having led the nearby Wood Elementary School for five years before taking over here this fall. The school has strong partnerships with Eli Lilly and Company, Mary Rigg Neighborhood Center, West Indianapolis Development Corporation, United Way Read Up, Tutor Mates, Boy Scouts, Indiana University Purdue University Indianapolis (IUPUI), and Indy Parks, and its website proudly states that it is indeed a community school.

CSC members from these five schools represent one of four distinct primary sectors of influence: school, community organizations, the private sector, and university. The cultural diversity of the CSC members represents the racial composition in most of the schools. Front and center, the CSC aims at developing successful engagement programs that acknowledge and address the cultural and linguistic competence of the students and families of the school communities.

\section{Problem statement: Unequal access to necessary education resources}

In 2014, the USDOE reported the nation had a problem of unequal access to educational resources and affirmed that "high-quality schools can make a dramatic difference in children's lives, closing achievement gaps, and providing students with the opportunity to learn and succeed in college and their chosen careers" (USDOE, 2014, p. 2). Access to resources can be a problem in any school; yet, urban schools located in low-income neighborhoods experience an increased lack of valuable resources. Often invisible to the administrators and teachers are the indiscernible signs of poverty, hunger, sleep deprivation, stress, and depression. According to Gorski (2005), a "deficit perspective" is an approach through which scholars explain varying levels of access and opportunity (educationally, professionally, and in other spheres) among groups of people by identifying deficits in the cultures and behaviors of the underprivileged group (p. 8).

A deficit perspective of poverty alienates positive approaches to resolving problems, making the disparities hard to see. Poverty is a multidimensional, complex dynamic and is context-specific, making it difficult to address through a one-dimensional view. In general, deficit models claim that the cause of underachievement lies within the individual rather than the system that creates the environment. For children in urban communities, the classroom culture or climate may not be conducive to learning due to the cultural incongruence of teachers and students (Nieto, 2012). The assumption is that the linguistic, social, and cultural nature of the home environment serves as an academic barrier to the work the students are required to do in school. Thus, the cultural deficit perspective places the cause of underachievement within an individual's cultural group by assuming the cultural groups cannot achieve just because of their cultural background (Valencia, 1997).

Teachers who work at these schools are challenged to meet the demands of academic success, often beyond their capabilities and knowledge of their students' culture or home situations. They feel the impact of poverty despite the availability of limited resources, which are often not adequate for closing the academic gap. Urban school districts consistently search for the elixir of learning that remedies low academic achievement without seriously considering the primary cause of most urban school problems. Poverty, the root cause of many economic and social conditions, cannot be controlled; yet, it controls the academic success of students. The achievement gap is hard to eliminate when success for many students depends on social and cultural factors that affect student performance (Berliner, 2009). The realistic roots of most achievement gaps are multiple, interrelated, and vary from school to school, district to district, and community to community.

Nevertheless, requiring all schools to meet the same high standards for all students, regardless of economic and social conditions, will inevitably lead to higher numbers of failing students and schools. Policies that disregard broader socioeconomic factors inherently prevent successful reform models from being fully realized. Realistically, the problem is exclusively not low-test scores, unmotivated students, disengaged parents, or unqualified teachers; the problem is far more systemic 
and requires a built-in community support system to serve as a structural asset for the success of students and their families.

\section{Methodology}

\section{Research design}

Our methodology for this inquiry is a community-based participatory action research approach as it assists community members in extending their understanding of their situations as they begin to communicate and comprehend the importance of their problems (Stringer, 2007). It is a collaborative approach to research that centers on building community capacity, leading to realization and readiness for action through small-scale theorizing (Denzin \& Lincoln, 1994). The authors served as participant researchers and, along with community leaders, developed a process to change community conditions and systems, creating a supportive environment in school communities to sustain behavior changes over time (Stringer, 2007). This approach to research can be used to pursue research objectives (knowledge, understanding) with the meaningful involvement of community members and an ultimate focus on social activities leading to improvements in social conditions as it engages "participants" as equals and full participants of the research by creating a "level playing field" where all stakeholders are valued (Stringer, 2007).

This work has translated into transformative programs and a synergistic partnership between communities and schools. We define action research as the systemic, collaborative learning process resulting in a profound, innovative understanding about community schools (Dadds \& Hart, 2001; McIntyre, 2008), where participants review their practices and identify aspects of the community school model they want to improve (Stringer, 2007). Key to the transformation is the leadership role of the CSC, the program director, and the community school coordinator or liaison as they organize efforts and present data and information to encourage the CSC members to reflect, analyze, and learn about their actions and, consequently, adopt new approaches or strategies in promoting the model. The five sample sites represent a range of grade levels as well as new and mature community schools. We see the transformation in the schools when issues are addressed, new relationships are formed, and frameworks appear. The decisions made by CSC become transformative in approaching problems, and in some ways, their transformative approaches enable CSC participants to become critically aware of the tensions and contradictions affecting their decisions at an individual, organizational, and structural level. Therefore, the need to collectively develop strategies that challenge the problems is necessary for assessing the collective impact they make. Collective impact is a concept and approach to solving social problems that remedies issues associated with isolated impact (Kania \& Kramer, 2011).

\section{Data collection and analysis}

Given that the CSC sampled in this study were all in schools within the same urban public school district, the researchers selected them based on location, community involvement, and amount of time working with the CSC. The team of researchers collected CSC meeting agendas, member reflections, and minutes from each of the schools. Notes from two CSC consultants highlighted their observations of the meetings and supplemental meeting minutes. We also reviewed the school demographic data and the services and programs offered by the community partners and reviewed two articles written about two of the five schools. We completed a triangulation of interview, observation, and documentary data on each variable to increase the validity of the results (Patton, 2014). We applied the interpretive and iterative processes of case study analysis in triangulating the stories of each school and the sources of data we gathered to compare the unique developmental events or best practices at the schools. Due to the size of the study, we assumed qualitative analytic techniques (Patton, 2014) were appropriate given the purpose of the research. 


\section{Interviews}

Three of the five principals involved in this study were interviewed to gather rich data concerning their understanding of the community school model. Two principals declined our invitation to interview. The interviews with the principals were conducted separately at each school and generally averaged about 90 minutes in length. The interview prompts included structured and open-ended questions.

\section{Observations}

In our observations of the CSC, we were particularly interested in examining the consistency of practices and policies at each school. The data described the nature of interactions among CSC members and the relationships they have with the school administrators. Although some of the observations were limited in scope and duration, the data illustrated a picture of the school. When combined with the results of interviews, questionnaires, and document review, they allowed us to explore the complex and overlapping realities of community school partnerships and the critical role of the CSC.

\section{Surveys}

The teacher surveys for this study were obtained from three sample sites that were involved in the community school study. Each year teachers are invited to participate in a Lunch and Learn Teacher Appreciation Luncheon where teachers complete a short survey about their knowledge and disposition about community schools. At all community member partnership meetings, participants completed a short questionnaire to measure their knowledge, beliefs, and relationship to community school activities at their school and their success and challenges. We also conducted small focus groups using non-structured questions to learn about their concerns with the community school process, service access, and program gaps. Teachers described what they thought were the successes and challenges related to community school programs at their schools.

\section{Review of the literature}

In the last decade, the community school movement has advanced as an innovative national strategy for addressing poverty, persistent inequities, and academic achievement. The emergent body of research suggests that community schools can play a critical role in supporting improved student outcomes (Anderson-Moore \& Emig, 2014; Blank, Melaville, \& Shah, 2003; Biag \& Castrechini, 2014; Bryk et al., 2010; Oakes et al., 2017). Community schools are a place-based strategy, where schools serve as the fulcrum for partners and community agencies that allocate resources to provide an "integrated focus on academics, health, and social services, youth and community development, and community engagement" (Coalition for Community Schools, n.d., para. x). The Coalition for Community Schools defines a community school as a public school-the hub of its neighborhood, uniting families, educators, and community partners to provide all students with top-quality academics, enrichment, health, and social services, and opportunities to succeed in school and life (http://www.communityschools.org/). The USDOE describes them as "public elementary or secondary schools that collaborate with local educational agencies (LEAs) and community-based organizations, non-profit organizations, and other public or private entities" (USDOE, 2014, as cited in Min, Anderson, \& Chen, 2017). These organizations form a partnership with the overarching goal of improving students' socio-emotional, physical, and academic needs. Orchestrating the work of the partnerships requires a site coordinator who serves as the official liaison between the school and the local community. This role is vital in building and maintaining relationships with local partners, engaging families, and streamlining services offered on-site at the school and the work of the community council.

Bryk et al. (2010) propose that a dedicated community-focused approach to education can support students and their families by collectively addressing their needs. According to their 
seven-year study, serious school reform must be built upon authentic family/school/community engagement. Researchers examined 200 turnaround schools in Chicago and found that only 10\% without consistent family and community engagement (or one of four other identified "essentials") realized academic gains (Bryk et al., 2010). Disparities in education are of paramount concern to policymakers, educators, and researchers (Carter \& Welner, 2013; Reardon, 2011). Bryk et al. (2010) state that students' academic learning occurs principally in classrooms as they interact with teachers around the subject matter. How we organize and operate a school has a significant effect on the instructional exchanges in its classrooms. Classroom learning extensively depends on how the school as a social context supports teaching and sustains student engagement (Bryk et al., 2010). Thus, community schools are a promising model for school reform, aiming to reduce risks (by meeting basic needs) and increasing learning opportunities (like afterschool enrichment programs) for students from impoverished backgrounds (Conwill, 2003; McMahon, Ward, Kline Pruett, Davidson, \& Griffith, 2000) as community partners play a critical role in delivering services and supports. It is a model that assures that all children, particularly disadvantaged children, have access to good schools and effective policies that provide access to quality education.

While there is limited research that examines the roles of community school councils supporting urban community schools, the work of the CSC is necessarily a network of partners of support. Activating broad participation by offering a diverse group of people the opportunity to share their talents and to become leaders while working collectively and building relationships; community organizing can grow the social capital of families, educators, and communities to improve school conditions (Oakes, Maier, \& Daniel, 2017). The subsequent social capital can be interpreted through relational trust and collective impact that recognizes each other's expectations and their commitments to the actions of all parties (e.g., administrators, teachers, parents) and validate expectations (Bryk \& Schneider, 2003). Conceptualizing social capital is an arduous task because, as Coleman $(1988,1990)$ points out, social capital exists between actors; it is not attributable to an actor like human and economic capital are attributable. Putnam $(1993,2000)$ treats social capital as a public good- the amount of participatory potential, civic orientation, and trust in others available to cities, states, or nations.

\section{Findings}

The summary of findings related to our research questions establish an understanding of the CSC's roles and strategies and the ways they implement and sustain the work. The themes and criteria selected from the research questions helped shape the findings, including five areas that respond to the research questions as we focused explicitly on the CSC practices and policies that support and align the site-level implementation of community schools. Consistent with the literature, the following four characteristics emerged from the data:

- collaborative leadership;

- family and community engagement;

- focused curriculum and instruction; and

- integrated, student supportive environment.

\section{Collaborative leadership}

When multiple school community stakeholders come together to solve complex social issues, the result is cross-sector coordination, and alignment of programs may naturally occur in the community (Blank, Berg, \& Melaville, 2006). Community councils provide the space for individuals with similar vested interests to put their heads and resources together to address myriad complex barriers to the necessary conditions for learning and positive youth development. Braiding resources and 
drawing on additional collectively identified assets throughout communities creates service delivery efficiencies and leverages fragmented resources that often can be overlooked or undetected (Klugman, Gordon, Bender Sebring, \& Sporte, 2015; Oakes et al., 2017). As stakeholders become more comfortable with one another, they discover additional mutual interests-sometimes outside of the school-based focus-that their collaboration could better address than doing so independently. Such synergy produces exponential gains throughout school communities, far beyond original goals or intent.

We found that in each of the schools with a community coordinator, parent involvement educator, or outreach director, the community school demonstrated a higher level of organization, preparation, and outcomes delivery or collective impact. For example, at the high school, the Dollars for Scholars program, Carson's coupon drive for the annual Community Day nonprofit fundraising sale, and Taste of the Westside were successful fundraisers because of the collaboration of multiple supportive partners to raise a significant amount of funds for postsecondary scholarships. When the school district threatened to close this school, it was the leadership of the CSC and collaboration of the partners that advocated for the school at the Mayor, City-County Council, and school board meetings. This collaborative effort secured the reopening of this high school in this neighborhood. When the middle school applied for "school administrative autonomy" to better serve the students and community, the CSC supported and actively promoted the application, a prime example of how the CSC serves as a critical external support for schools. This school became one of three schools to receive the special district status. Middle school teachers working on building-level student learning programs collaborate with the whole council and facilitate the discussion on how best to use the assets of the partnerships to support student learning as part of strategies related to their School Improvement Plan.

Active collaboration with key community partners made a significant impact in the school leadership when a partner neighborhood center embedded a Community School Coordinator in the high school and facilitated leadership of the council meetings. As a member of the School Leadership Team, the community school coordinator collaborated with the principal in communicating with the partners and orchestrating services and programs for the school. Conversely, we found that when school leadership was not fully vested or engaged in council activities, academic achievement, student attendance, and high school graduation decreased significantly. As the number of partners and volunteers declined, there was less academic support for students. While the high school students experienced a loss, so did university students who lost an opportunity to gain valuable experience in supporting student learning, strengthened family and community engagement, and related leadership skills.

In their research about high-quality schools, Oakes et al. (2017) found that collaborative leadership, practice, and relationships demonstrated in community schools could create the conditions necessary to improve student learning and well-being, as well as improve relationships within and beyond the school walls. We found that the CSC was responsible for grassroots planning for the school that began at the community school council meeting. Through the facilitation of small group discussions, all of the community school councils engaged partners in problem-solving by focusing on ways that they could help students. For example, at the high school, the following question was posed: How could we help the 612 students succeed? If community support and teacher-peer learning appear to be the factors that explain the link between collaboration and better student achievement, then we can state that the development of social capital by the CSC should emphasize social trust, norms, and relational networks (Coleman, 1990).

\section{Family and community engagement}

A key aspect of community schools is inviting parents and community members to work as partners in decision-making about supportive services and academic achievement. This collaboration creates an opportunity for a shared partnership and responsibility between home and school. It is an integral 
element of school improvement and establishing a trusted learning environment. Family and community engagement can be a powerful tool for making schools equitable, culturally responsive, and collaborative, committing school leaders and parents as a vital unit to academic achievement (Noguera, 2001; Olivos, 2006).

Family engagement in urban schools is not simple. It requires more than an invitation to eat cookies and drink punch at an evening event. Each of the community schools in this study has adopted different approaches to family engagement. Some schools have hired parent involvement coordinators that organize programs that are beneficial to parents (Epstein \& Becker, 1982). Not all community schools have a dedicated person who works specifically with parents; however, each school has a CSC that focuses on long-term parental engagement. As previously stated in this article, deficit views of urban parents often become the barrier to successful parent engagement. Different from most schools is the disposition of the members of the CSC, particularly ones with parent members. We found that the community councils focus on the ways they can engage parents by developing authentic working relationships with a small team of parents. For example, the goal of one CSC, as stated in their minutes, is to provide a sense of community and inclusive involvement of service providers, administrators, teachers, staff, students, and families to feel welcomed, valued, and empowered. They want to give parents a reason for being involved in the CSC by including parents in solving problems at the school. An example of the power of family engagement is the work of the parent leadership team at an elementary school that took the lead in acquiring student supplies like clothes and classroom materials. In another elementary school, parents took the lead in running a food pantry; they are involved in the school Parent Teacher Association (PTA) and participate in most family activities. This elementary CSC membership features youth development, corporate, parent, multi-service center, faith-based, city government, university, health and fitness, science and industry, philanthropic, teacher, administrator, and staff representatives. At the high school, family engagement nights were the hallmark of the school as they experienced more than $54 \%$ of the students' parents involved in at least twofamily engagement activities. While the numbers show success at one school, each school continues to work with the CSC to increase family engagement.

Through the leadership of the CSC, most of the schools have maintained consistent engagement with anchor community organizations, including the university and multiservice centers that continue to collaborate in various ways in the stability and sustainability at the schools. Their work supports the CSC and is consistent at each school. Despite multiple ongoing changes in school principals, organization leaders, and community mobility, through all of the transitions, the strong backbone of support providing and aiding in creating a shared sense of purpose in serving the students, families, and community in their neighborhoods has been the faculty and staff of nearby IUPUI. The long-term commitment and participation rely on communication through relationshipbuilding, on-going dialogue, and collaboration and authentic engagement amongst the collective body of partners who help maintain the initiative.

One school was explicitly interested in improving school climate and discussed ways to reduce school suspensions and absences and improve academic achievement. Working with the School Improvement Plan for the next two years, the school improved standardized test and end-of-course assessments scores. Conversely, in another school that was also interested in improving the school climate, the CSC discussed ways to do so, but the principal reported the school would increase the number of behavioral specialists to control students instead. This idea was dramatically different from a principal who reported that the standardized test had low results and requested that partners consider creative strategies and interventions to help improve math and language arts achievement. Here, the CSC established a more inclusive and cognitive thinking strategy to resolving the problem instead of focusing only on student behavior. 


\section{Focused curriculum and instruction}

According to Oakes et al. (2017), students benefit when schools offer multiple opportunities for families, including information about supporting student learning to embracing strategies that encourage parents' participation in influencing local education policy. We found that successes and challenges in this area depended on the disposition of the school principals and their understanding of the impact the CSC has on the decisions they make about the curriculum, including during and after school programs. Principals who trusted the CSC process and who were aligned with the community school tenants were more inclined to ask for assistance. For example, due to the loss of state and district funding, the high school principal requested assistance in helping with high school senior events. At the CSC meeting, the partners identified resources in the community to help students with extracurricular activities. While the primary benefits of such programs are often understudied, underreported, or not viewed as a direct impact on the school curriculum and instruction, we see the high power of afterschool experiences on student learning. Various studies demonstrate how youth involvement with during and after school programs can increase academic achievement (Adams, 2010), decrease drug use, prevent criminal behavior, increase moral values, provide safe refuge during some of the most unsafe hours of the day for children, and strengthen self-confidence (Durlak \& Weissberg, 2007; Naftzger et al., 2007).

As we reviewed the data, we found that in all CSC meetings, parent, community, student, and educator participants collectively reviewed student and neighborhood demographics, academic achievement, attendance statistics, and social/emotional status. This analysis led to the identification and alignment of the learning supports that were necessary for student success. The CSC collaboration has resulted in the development and implementation of the school improvement plans. After three years, when the CSC participated in this school improvement planning process, the high school experienced its most significant academic growth over the past two decades. Much of the success can be attributed to the number of tutors available to students and the intentionally aligned increased volume of services.

The data from all five community schools confirms that the CSC depended heavily on the annual review process of the school data, as well as the identification of internal and external strengths and threats to academic performance. Discovering the strengths and challenges helped them keep the focus on creating the necessary conditions for learning, which directly contributed to a positive and more effective learning environment.

Oakes et al. (2017) found evidence that community schools can meet the needs of low-achieving students in high-poverty schools and help close opportunity and achievement gaps for students from low-income families, students of color, English learners, and students with disabilities. To do this work, authentic collaboration must be intentional, and the CSC must drive the work to achieve their goals. During the 2016/2017 school year, an elementary school CSC targeted chronic absenteeism, as $61 \%$ of students had missed 10 or more days of school. In small working groups, we observed how the CSC created universal strategies to focus on student attendance through family engagement activities, ameliorating out-of-school barriers to teaching and learning in several schools. The strategies included the creation of small teams who conducted home visits and an interdisciplinary case management system that addressed issues that prevented students from attending school.

\section{Integrated student supportive environment}

The efforts to improve school culture, climate, and learning environments are not separate strategies or one-time endeavors. The strategies must be assessed, designed, funded, and implemented as a comprehensive, holistic approach that facilitates interdisciplinary collaboration and builds on a multitiered system of supports that are blended and braided within the school community. This long-term constant process urges changes in policies and practices that will equip all schools to educate and provide services to children and their families. Community schools can develop high-quality learning 
experiences to improve long-term educational outcomes for students and their families; yet, this work can be particularly challenging in urban communities where families with low incomes are working full time, often in multiple jobs. We know that no single federal or state funding source can adequately address both of these needs and education programs for the student; therefore, service providers combine existing funding streams through collaborative resources. In this study, we found multiple examples of effective "blending and braiding" of programs as a way to sustain the efforts. Blending refers to allocating two or more funding sources for a specific initiative to a group of people. Braiding refers to combining two or more funding sources to support services for an individual child and that are tracked by categorical funding sources (Wallen \& Hubbard, 2013).

An excellent example of this collaboration was the way the middle school served as a pilot site for implementing a positive-based student behavior program. With the support of multiple council partners, the school received accolades for the implementation outcomes thus far in their school community. The outcomes included significantly reduced behavioral incident reporting and suspensions, strengthened communication skills for youth and adults, and a school climate among all stakeholders that provided a positive learning environment.

Another example is the relationship between the city parks and recreations department and the high school aquatics center. The city maintained the pool and provided the lifeguards for students during the school day. The city parks and recreation department utilized the pool for city-wide programming for afterschool and weekend activities. A similar relationship existed with the high school and the university physical education and physiology science department, where college students managed the fitness center afternoons and evenings for area students and adults. Meanwhile, at the onsite clinics in the schools, various partners were funded by multiple sources to provide primary health care services to students. Community mental health therapists also provided onsite counseling to students and their families. One elementary school has implemented a school-wide social/emotional initiative with the help of a community mental health partner. The initiative allowed faculty and staff the opportunity to participate in professional development on trauma-recognized strategies.

In one elementary school, a 25-year partnership with a corporate partner provided a variety of supports for classroom teachers, students, and their families. Two elementary schools benefited from a nonprofit partner who provided access to community-wide college preparation and annually sent sixth graders and their families on local college visits. After several years of providing this support, the collaboration with the colleges, schools, and parents was seamlessly making it easier for students and their parents to have access to postsecondary education and has created a self-described "college-going community."

In addition to these four elements, two additional characteristics emerged from this study: (1) external advocacy and (2) stakeholder diversity, parity, and equity. We believe these findings are unique to school communities caught in the firestorms of reform movements supported by punitive educational policies. For nearly two decades, the city has developed a vision for education that has worked toward creating a competitive market-driven system based on privatization schemes and high stakes test-driven curriculum. This city was first in the nation to establish its charter school experiment after the state passed a law in 2001, and the city council gave the mayor the power to authorize charter schools within the city. Here, it is important to note that the public school district is entirely autonomous to the mayor's office. The consequences of this appointment created a myth that "fixing" a "broken" public school system that is incapable of preparing youth for future challenges was now the role of city government. The impression by community school leaders in this school district is that the constant threat of school takeover was driven by a broader neoliberal agenda that had little regard for the thoughts of the communities it affected. While public schools may need resources and investment, they continue to play an essential role in the daily fabric of life in communities. Thus, more than ever, the role of the CSC has focused on becoming external advocates and being inclusive as they strive for stakeholder diversity, parity, and equity. 


\section{External advocates}

Inspired by the courage of parents to protect their children and the spirit of public education, we learned how CSCs served as external advocates for their schools. Motivated by the pressure of school takeovers and market-oriented measures to reform schools, two CSCs fought the Superintendent's blueprint for reorganizing the district. Veiled as a "parent choice strategy," the decision to close or take over schools failed to consider the impact it would have on full-service community schools and the notion that the schools belong to the community.

For example, last year, the school board decided to close three high schools due to low enrollment. The threat of closing the high school in this study forced the CSC to organize members to attend every public hearing to support the school, protest in front of the school district building before the board meetings, and provide testimonies at school board meetings to advocate for keeping the high school open. After months of public comment and debate, the board voted to keep this high school open. According to several members of the CSC, the diversity, strength, and synergy of the CSC members, including parents, teachers, alumni, students, and community members, helped keep the school open.

The transformation of the middle school into a model autonomous school within the district followed multiple CSC meetings where the notion was a topic of discussion, partner participants identified alignment between autonomy and support services, and CSC members provided external evidence of support for autonomy in written and verbal opportunities with district leadership. Continued engagement and support by the CSC contributed to the school serving as a model for the implementation of autonomous status throughout the district.

\section{Diversity, parity, and equity}

Addressing issues of cultural competency is outside the scope of this study; however, we recognized the cultural diversity of the families we served, and that family and community engagement initiatives needed to identify the importance of cultural diversity in addressing complex issues in cross-cultural situations (Cross, Bazron, Dennis, \& Isaacs, 1989). The development of stakeholder diversity, parity, and equity are critical to the development of the CSC as it allows for a diverse community-wide perspective of thought and support, particularly in the identification of barriers to learning and access to necessary resources to address them (Grim et al., 2011). We observed how the cultural diversity of the CSC could provide meaningful, culturally rich discussions and strategies for addressing Latinx family engagement. For example, in schools that had a growing Latinx population, the CSC intentionally recruited Spanish-speaking members or leaders who worked closely with the Latinx community. Much of this work evolved from the discussions we had with teachers who expressed an interest in obtaining bilingual educational material to engage students and their parents. Teachers and staff also wanted to learn more about the cultural needs of the students. One principal praised her Latinx parent engagement coordinator for her efforts in creating events that bridge the school and Latinx community.

\section{Discussion}

The famous adage "education is the great equalizer" is misleading for children who have unequal access to quality education (Hanushek, 2010). Jonathan Kozol (1992) reminds us that the savage inequalities of schooling and the inequitable distributions of resources impair students who are held to the same standards as students who attend privileged schools. The perils of high-stakes testing to assess student learning and school performance, often critical and punitive, reminds us of the realities and opportunities of students who live in financially struggling neighborhoods. Thus, addressing the lack of access to learning opportunities is critical in closing the ever-growing achievement gaps. Over-simplistic solutions to complex problems based on stereotypes, instead of 
cultural realism, become norms for overwhelmed school systems that tend to diminish the intellectual capabilities of students while discounting cultural values and behaviors of urban school families.

While there are many examples of successful community schools, there are limitations to the development and success of the urban community school. Few programs address all student needs and are counterproductive when the implementation and delivery system is flawed by the lack of fidelity of the model (Bryk et al., 2010). Although many students benefit from services, the assumption is that the provision of the services and resources will translate to high academic achievement. In other words, as the services to students increase, so do the expectations for higher achievement (Houser, 2010). Community school councils distinctly address the right conditions for learning rather than dictate how teachers teach or how students learn. Thus, teachers are better prepared to teach, and students are better prepared to learn.

We believe the CSC must, therefore, address two significant assumptions. First is the assumption that institutional structures of schooling will reform and address the educational inequities that exist in urban schools. Second, acknowledging that the curriculum often predisposes students to increased alienation and lack of academic engagement. Therefore, a responsive curriculum can serve as a guide in addressing the long-lasting, devastating effects it has on the academic outcomes as students actively create knowledge influenced by their own lived experiences. The evidence missing from the assumptions about the effectiveness of community schools is that leadership and teaching matter, and high-quality teaching can remove the socioeconomic barriers that distress students (Hanushek, 2005).

The evolution of leading a child to adulthood is complex and beyond the resources of any one institution. Blaming teachers, parents, or administrators for the current socioeconomic conditions that distress student learning fails to consider the multiple factors that make students vulnerable. Hence, the role of the CSC must include external advocacy and active democracy that wholeheartedly and courageously embraces the connection to the community and protects the school from the evolving privatization of public-school paradigm.

Community school councils provide the deliberate space for ongoing collaborative engagement between educators, parents, service providers, and community partners in coordination and academic alignment of necessary supports for learning. Research led by Bryk (2010), Oakes, Maier, \& Daniel, (2017), and others demonstrates that family and community engagement in matters pertinent to school improvement strategies, organized implementation, and related positive youth development activities help to predict success through the collective impact. The CSC process enhances collaborative school leadership, focused curriculum and instruction, and an integrated student supportive environment, all of which are tenets of the CSC engagement, and all demonstrated as necessary for actual school improvement. The CSC student achievement data and assets/needs assessment analysis identifies internal and external strengths and threats to academic performance and school success and positions the collaborative process as particularly valuable for educators, students, their families, and neighborhoods. This attention directly contributes to positive student behavior supports and an overall positive learning environment, naturally seeding increased student success. CSC collaboration enables service providers and community partners to more efficiently and effectively exercise their supports through the hub of the community: the school, where students and their families naturally interconnect.

The collaborative, coordinated CSC engagement provides administrators, teachers, staff, students, and families with a sense of being welcome, valued, and empowered. The impact is reflected with increased student and staff school attendance, greater extra-curricular engagement, and curriculum relevance through community-based service-learning activities. Students gain valuable experience in community building to support student learning and critical civic and career leadership skills. Meanwhile, families are supported and strengthened, and the community shares with educators in the responsibility for the education of its youth. Judicious school leaders recognize and embrace the value of CSC collaboration that instills genuine advocacy for the school community. 
Indeed, the call for school reform requires a community engagement strategy centered on intermingled social problems including poverty, racial isolation and discrimination, cultural clashes, socioeconomic inequalities, and resource disparities (Anyon, 2009, 2005; Kozol, 2005; McLaren, 2006). Limited time and resources require committed partnerships that support schools to advance learning. Community School Councils are the demonstrated organizing strategy that squarely focuses collaborative attention on addressing potential threats and enhancing strengths for student, family, and neighborhood success. The five schools of this study serve as prime examples.

\section{Conclusion}

In this study, we sought to understand three essential questions related to the roles of community school councils that focus explicitly on community school council practices in five urban community schools. We focused on the experiences of the CSC and found evidence of four tenants supported by the Bryk model for school improvement: (1) collaborative leadership, (2) family and community engagement, (3) focused curriculum and instruction, and (4) integrated, supportive student environment. Also, our study supports two additional foundational components specific to the implementation and sustainability of urban community schools: external advocates and diversity, parity, and equity.

School leaders in this study also recognized that community school councils with a community coordinator, parent involvement educator, outreach director, or related building-level professional demonstrate a higher level of organization, collaboration preparation, service delivery, and collective impact. While each school has its own story of success and challenges, the implementation and continuous assurance of community schools have resulted in sustained community partnerships. Thus, the number of partners and members of the CSC continue to change as each school identifies the needs of students and their families. Each school is unique, so intentionally there is no control group among them to compare schools or impact measure based on the normative or universal view. In this case study, it is impossible to construct a counterfactual account of what might have happened absent the development of the CSC at each school.

\section{Author bios}

Monica A. Medina is a Clinical Associate Professor at the Indiana University School of Education at the Indiana University Purdue University at Indianapolis campus and has been engaged in the community schools field of study for the past two decades. As a participatory action researcher, civic-engaged faculty member, she has been the principal investigator of three U.S. Department of Education five-year evaluations of the school communities.

Jim Grim is Director of University/Community School Partnerships in the Office of Community Engagement at IUPUI. A former high school teacher and adjunct university faculty member, he became engaged in community schools work 25 years ago. He and Dr. Rita Brodnax have collaborated as consultants in Indianapolis for Community School Council development for six years.

Gayle Cosby is a doctoral student and Graduate Assistant in the IUPUI Urban Education Studies program. She brings a rich and diverse body of knowledge and experience from her previous roles as a Special Education Teacher, an administrator of an after-school program, a parent, and a former Commissioner of the board of Indianapolis Public Schools.

Rita Brodnax has culturally diverse and in-depth education field experience as a teacher, administrator, professional development coordinator, technology director, dean, superintendent, university faculty, and state education department consultant. As CEO of Brodnax's Better Brains, she focuses on strategies to demonstrate "brain compatible learner experiences" to ensure learning, sustainable memory, and positive brain growth.

\section{References}

Adams, C. (2010). The community school effect: Evidence from an evaluation of the Tulsa Area Community School Initiative. Tulsa: University of Oklahoma, The Oklahoma Center for Educational Policy. 
Anderson-Moore, K., \& Emig, C. (2014). Integrated student supports a summary of the evidence base for policymakers. Child Trends White Paper, 2014-05. Washington, DC: Child Trends.

Anyon, J. M. (2005). Radical possibilities: Public policy, urban education, and a new social movement. New York, NY: Routledge.

Anyon, J. M. (2009). Theory and educational research: Toward critical social explanation. New York, NY: Routledge.

Berliner, D. C. (2009). Poverty and potential: Out-of-school factors and school success. Boulder: Education and the Public Interest Center, University of Colorado/Education Policy Research Unit, Arizona State University.

Biag, M., \& Castrechini, S. (2014). The links between program participation and students' outcomes: The Redwood city community schools project. (W. John, Ed.). Stanford, CA: Gardner Center for Youth and their Communities.

Blank, M. J., Berg, A. C., \& Melaville, A. (2006). Growing community schools: The role of cross-boundary leadership. Washington, DC: The Coalition for Community Schools.

Blank, M. J., Melaville, A., \& Shah, B. P. (2003). Making the difference: Research and practice in community schools. Washington, DC: Coalition for Community Schools.

Bourdieu, P. (1986). The forms of capital. In J. Richardson (Ed.), Handbook of theory and research for the sociology of education (pp. 241-258). New York, NY: Greenwood Press.

Bryk, A., \& Schneider, B. (2003, March). Trust in schools: A core resource for school reform. Educational Leadership, 60(6), 40-45.

Bryk, A. S., Sebring, P. B., Allensworth, E., \& Luppescu, S. (2010). Organizing schools for improvement: Lessons from Chicago. Chicago, IL: University of Chicago Press.

Carter, P. L., \& Welner, K. G. (2013). Closing the opportunity gap: What America must do to give every child an even chance. Oxford: Oxford University Press.

Coalition for Community Schools. (n.d). What is a community school? Washington, DC: Coalition for Community Schools. Retrieved on June 2, 2018, http://www.communityschools.org/aboutschools/what_is_a_community_ school.aspx

Coleman, J. S. (1988). Social capital in the creation of human capital. The American Journal of Sociology, 94, S95. doi: $10.1086 / 228943$

Coleman, J. S. (1990). Foundations of social theory. Cambridge, MA: Harvard University Press.

Conwill, W. L. (2003). Consultation and collaboration: An action research model for the full-service school. Consulting Psychology Journal: Practice and Research, 55(4), 239. doi:10.1037/1061-4087.55.4.239

Cross, T., Bazron, B., Dennis, K., \& Isaacs, M. (1989). Towards a culturally competent system of care (Vol. I). Washington, DC: Georgetown University Center for Child and Human Development, CASSP Technical Assistance Center.

Dadds, M., \& Hart, S. (2001). Doing practitioner research differently. London, UK: Routledge.

Denzin, N. K., \& Lincoln, Y. S. (1994). Handbook of qualitative research. Thousand Oaks, CA: SAGE.

Durlak, J. A., \& Weissberg, R. P. (2007). The impact of after-school programs that promote personal and social skills. Chicago: Collaborative for Academic, Social, and Emotional Learning. Retrieved from http://www.casel.org/down loads/ASP-Full.pdf

Epstein, J. (2009). School, family and community partnerships; Caring for the children we share. In School, family and community partnerships: Your handbook for action (3rd ed., pp. 8-12). Thousand Oaks, CA: Corwin.

Epstein, J. L., \& Becker, H. J. (1982). Teachers' reported practices of parent involvement: Problems and possibilities. The Elementary School Journal, 83(2), 103-113. doi:10.1086/461298

Gorski, P. (2005). Education equity and the digital divide. Association for the Advancement of Computers in Education Journal, 13(1), 3-45.

Grim, J., Medina, M. A., \& Officer, S. D. H. (2011). A decade of lessons: Community engagement perspectives from a university-assisted school community. Indianapolis, IN: Midwest Center for University-Assisted Community Schools, Center for Service and Learning, Indiana University Purdue University Indianapolis.

Hanushek, E. A. (2005). Our school performance matters. Journal of Education, 185(3), 1-6. doi:10.1177/ 002205740518500303

Hanushek, E. A. (2010, Summer). An effective teacher in every classroom: A lofty goal, but how to do it. (with Kati Haycock). Education Next, 10(3), 46-52.

Houser, J. (2010). Program participation and academic achievement in a full-service community school (submitted in partial fulfillment of the requirements for the degree Doctor of Philosophy). Bloomington: Department of Counseling and Educational Psychology, Indiana University School of Education.

Indianapolis Public Schools. (n.d.). Our history/Mission - Indianapolis public schools. Retrieved from https://www. myips.org/Page/2505

Kania, J., \& Kramer, M. (2011). Collective impact. Stanford Social Innovation Review, 9(1), 36-41.

Klugman, J., Gordon, M. F., Bender Sebring, P., \& Sporte, S. (2015). A look at the 5 essentials in Illinois schools. Chicago, IL: The University of Chicago Consortium on Chicago School Research.

Kozol, J. (1992). Savage inequalities: Children in America's schools. New York, NY: Harper Perennial.

Kozol, J. (2005). Shame of the nation: The restoration of apartheid. New York, NY: Random House.

Lubell, E. (2011). Building community schools: A guide for action. New York, NY: Children's Aid Society. 
Maier, A., Daniel, J., Oakes, J., \& Lam, L. (2017). Community schools as an effective school improvement strategy: A review of the evidence. Palo Alto, CA: Learning Policy Institute.

Maier, A., Daniel, J., Oakes, J., \& Lam, L. (2018). Community schools: A promising foundation for progress American Federation of Teachers. Retrieved from https://www.aft.org/ae/summer2018/maier

McIntyre, A. (2008). Participatory action research. London, UK: Sage.

McLaren, P. (2006). Rage+Hope. New York, NY: Peter Lang.

McMahon, T., Ward, N., Kline Pruett, M., Davidson, L., \& Griffith, E. (2000). Building full-service schools: Lessons learned in the development of an interagency collaborative. Journal of Educational and Psychological Consultation, 11(1), 65-92. doi:10.1207/S1532768XJEPC1101_5

Min, M., Anderson, J., \& Chen, M. (2017). What do we know about full service community schools: Integrative research review with NVivo. The School Community Journal, 29-54.

Naftzger, N., Bonney, C., Donahue, T., Hutchinson, C., Margolin, J., \& Vinson, M. (2007). An overview of the 21 st CCLC program: 2005-06. Naperville, IL: Learning Point Associates.

Nieto, S. (2012). Honoring the lives of all children: Identity, culture, and language. In B. Falk (Ed.), Defending childhood: Keeping the promise of early education (pp. 48-62). New York, NY: Teachers College Press.

Noguera, P. (2001). Transforming urban schools through investments in the social capital of parents. In M. Warren (Ed.), Social capital in poor communities (pp. 189-212). New York, NY: Russell Sage Foundation.

Oakes, J., Maier, A., \& Daniel, J. (2017). Community schools: An evidence-based strategy for equitable school improvement: A review of the evidence. Palo Alto, CA: National Education Policy Center and Learning Policy Institute.

Olivos, E. M. (2006). The power of parents: A critical perspective of bicultural parent involvement in public schools. New York, NY: Peter Lang.

Patton, M. (2014). Qualitative evaluation methods (4th ed.). Beverly Hills, CA: Sage Publications.

Putnam, R. D. (1993). What makes democracy work? Nat Civic Rev, 82, 101-107. doi:10.1002/ncr.4100820204

Putnam, R. D. (2000). Bowling alone: The collapse and revival of American community. New York, NY: Simon \& Schuster.

Reardon, S. (2011). The widening academic achievement gap between the rich and the poor: New evidence and possible explanations. In G. Duncan \& R. Murnane (Eds.), Whither opportunity? Rising inequality, schools, and children's life chances (pp. 10-16). New York, NY: Russell Sage Foundation.

Stringer, E. T. (2007). Action research: A handbook for practitioners. California, USA: Sage.

U.S. Department of Education, Office for Civil Rights. (2014). Dear colleague letter: Resource comparability. Washington, DC: U.S. Department of Education. http://www2.ed.gov/about/offices/list/ocr/letters/colleagueresourcecomp-201410.pdf

Valencia, R. R. (1997). The evolution of deficit thinking. New York, NY: Routledge.

Wallen, M., \& Hubbard, A. (2013). Blending and braiding early childhood program funding streams toolkit: Enhancing. financing for high-quality early learning programs. (Version 2). Chicago, IL: Ounce of Prevention Fund. Retrieved from https://www.theounce.org/wp-content/uploads/2017/03/NPT-Blended-Funding-Toolkit.pdf

Warren, M., Thompson, J. P., \& Saegert, S. (2001). The role of social capital in combating poverty. In S. Saegert, P. Thompson, \& M. Warren (Eds.), Social capital and poor communities (pp. 1-28). New York, NY: Russell Sage.

Yin, R. (1984/1994). Case study research: Design and methods. Thousand Oaks, CA: Sage. 